\title{
Palynology and clay mineralogy of the Deccan volcanic associated sediments of Saurashtra, Gujarat: Age and paleoenvironments
}

\author{
Bandana Samant $^{1, *}$, D M Mohabey ${ }^{2}$, P Srivastava $^{3}$ and Deepali Thakre ${ }^{1}$ \\ ${ }^{1}$ Department of Geology, Rashtrasant Tukadoji Maharaj Nagpur University, Nagpur 440 001, India. \\ ${ }^{2}$ Geological Survey of India, Northern Region, Aliganj, Lucknow 226 007, India. \\ ${ }^{3}$ Department of Geology, University of Delhi, Delhi 110 00\%, India. \\ *Corresponding author. e-mail: bandanabhu@gmail.com
}

The intertrappean sediments associated with Deccan Continental Flood Basalt (DCFB) sequence at Ninama in Saurashtra, Gujarat yielded palynoassemblage comprising at least 12 genera and 14 species including Paleocene taxa such as Intrareticulites brevis, Neocouperipollis spp., Striacolporites striatus, Retitricolpites crassimarginatus and Rhombipollis sp. The lava flows of Saurashtra represent the northwestern most DCFB sequence in India. It is considered that the Saurashtra lava flows represent the earliest volcanic activity in the Late Cretaceous of the Reunion Mantle Plume on the northward migrating Indian Plate. The present finding of the Paleocene palynoflora from Ninama sediments indicate Paleocene age for the associated lava flows occurring above the intertrappean bed which suggests that the Saurashtra plateau witnessed eruption of Deccan lava flows even during Paleocene. The clay mineral investigation of the Ninama sediments which are carbonate dominated shows dominance of low charge smectite (LCS) along with the presence of mica and vermiculite. Based on the clay mineral assemblage it is interpreted that arid climatic conditions prevailed during the sedimentation. The smectite dominance recorded within these sediments is in agreement with global record of smectite peak close to the Maastrichtian-Paleocene transition and climatic aridity.

\section{Introduction}

Deccan Continental Flood Basalt (DCFB) presently covering over $500,000 \mathrm{~km}^{2}$ is considered as one of the largest continental flood basalt eruptions in the earth's history (Jay and Widdowson 2008). The influence of Deccan volcanism on contemporary environments and biota is still under investigation. The paleontological and sedimentological studies of the sedimentary beds associated with the DCFB sequences in the last one decade has improved our understanding on the environmental changes associated with the Deccan volcanism specially in relation to the Cretaceous-Paleogene boundary $(\mathrm{K}-\mathrm{Pg} \mathrm{b})$ and its effect on the biota (Bajpai and Prasad 2000; Prasad and Pundeer 2002; Hansen et al. 2005; Keller et al. 2008, 2009, 2011).

The volcano-stratigraphy of the DCFB sequences exposed in parts of central India, southern province, eastern Mandla lobe including easternmost outcrops of Ambikapur, Satpura region and of the Bagh valley towards north of Narmada River has been well established based on flow-wise

Keywords. Palynology; clay mineralogy; intertrappean; Deccan Continental Flood Basalt (DCFB); Paleocene; Paleoclimate. 
mapping on 1:50,000 scale, petrogenetic study, magnetostratigraphy and geochemistry of both major and trace elements (Deshmukh 1980, 1984; Cox and Hawkesworth 1984; Beane et al. 1986; Courtillot et al. 1986; Nair et al. 1996; Nair and Bhusari 2001; Jay and Widdowson 2008). The DCFB sequences of these regions have been classified as Sahyadri Group, Amarkantak Group, Satpura Group and Malwa Group (figure 1a). The knowledge generated in the last two decades by the study of lithostratigraphy, chemostratigraphy and magnetostratigraphy of the DCFB sequences along with palynostratigraphy has provided age constraint and helped in establishing their stratigraphic correlation (Subbarao et al. 1994; Hopper 1999; Widdowson et al. 2000; Hansen et al. 2001; Samant and Mohabey 2005, 2009; Jay and Widdowson 2008; Jay et al. 2009). However, establishing the stratigraphy of DCFB sequences in Kutch and Saurashtra in Gujarat which represents the northwesternmost outcrops on the Indian subcontinent has remained challenging. In this part, the DCFB sequences could not be formally classified (Fedden 1884; Auden 1949, reprint from 1999) in spite of the flow-wise mapping and petrogenetic studies. The flows of the DCFB sequences in these regions are considered to be the oldest Deccan flows derived from the Reunion Hotspot Mantle Plume concurring with the northward migration of the Indian Plate (West 1950; reprint from 1999; Widdowson et al. 2000). The lava flows are represented by basic, acidic and alkaline volcanic rocks and their derivatives associated with dyke swarms (Krishnamurthy et al. 1999).

In Saurashtra, the first record of any fossil from intertrappean beds is from the localities at Ninama and Bamanbore. Fedden (1884) was the first to record fragmentary fossil fish skeletons of Horaclupea intertrappea and Paleopristolepis feddeni along with Perca cf. angusta and a few percoid fish scales in the sediments. Later on Borkar (1973, 1986) also recorded fish remains of Paleopristolepis chiplonkari and gastropods (Physa) from both these localities. However, since the last two decades no additional paleontological studies have been conducted for any intertrappean sedimentary beds in the area.

The findings presented here are a result of paleontological studies of Deccan volcanic associated intertrappean sediments at different stratigraphic levels in Saurashtra. The study of the sediments was basically aimed at assessing the impact of volcanism on the contemporary flora and the environments and for establishing their stratigraphic correlation with the known DCFB associated sediments in the regions of Kutch and central India. The present study shows presence of palynoassemblage from the intertrappean sediments at Ninama in Surendranagar District. The finding is significant for being the first report of palynomorph bearing intertrappean sediments from Saurashtra and also for bridging the gap in the knowledge of palynofloral records from the widely separated DCFB sequences of western, central and southern provinces.

\section{Geological setting}

The Saurashtra peninsula is considered as a cratonic horst surrounded by rift graben (Biswas and Deshpande 1983) and the NNW-SSE and the NNE-SSW trending lineaments in the western and the eastern parts, respectively (Mishra 1999). A major part of the peninsula is covered by Deccan volcanic flows. In the northeastern part, the DCFB sequence overlies the Mesozoic group of sediments. Along the coast from Dwarka to Bhavnagar the DCFB are overlain by rocks of Paleogene age. Pleistocene Miliolite Formation covers all the rock types in the area. Earlier subsurface drilling in the eastern part of Saurashtra peninsula in Wadhwan, Dhanduka and Botad showed presence of 48 flows (West 1999). Petrographic study of these flows indicates that the flows were derived from the basaltic magma of tholeiitic type that were first to extrude followed by acidic magmatism and the swarms of basic dykes (West 1999). Central type of explosive eruptions have been reported from the Loingde-Bhaguda area in south eastern Saurashtra, having volcanic bombs of various sizes ranging from pin head to about $15 \mathrm{~cm}$ embedded in Rhyolite and Obsidian (Mishra 1999). In the study area, the DCFB sequence rests either over the Lower Cretaceous Dharangadhra Formation or Upper Cretaceous Wadhwan Formation. Shekhavat and Sharma (1996) reported 13 flows varying in thickness from $10 \mathrm{~m}$ to $80 \mathrm{~m}$. They also reported five intertrappean beds in the Wakaner-Rajkot area at different stratigraphic levels. Presently, there is no data available on the radiometric or paleomagnetic age of the Deccan lava pile of Saurashtra and hence geochronological age constraint for the sediments and associated lava flows is totally lacking. It is in this context that the present find of palynoassemblage indicating a Paleocene age for the Ninama intertrappean sediments is significant.

During our investigation in Saurashtra we studied intertrappean sediment at different stratigraphic levels in nine localities (figure 1b, table 1). The sediments at Jalsika represent the intertrappean exposed at lowest stratigraphic level whereas the Bamanbore-Wakaner Road section represents the intertrappean at the highest stratigraphic level. 

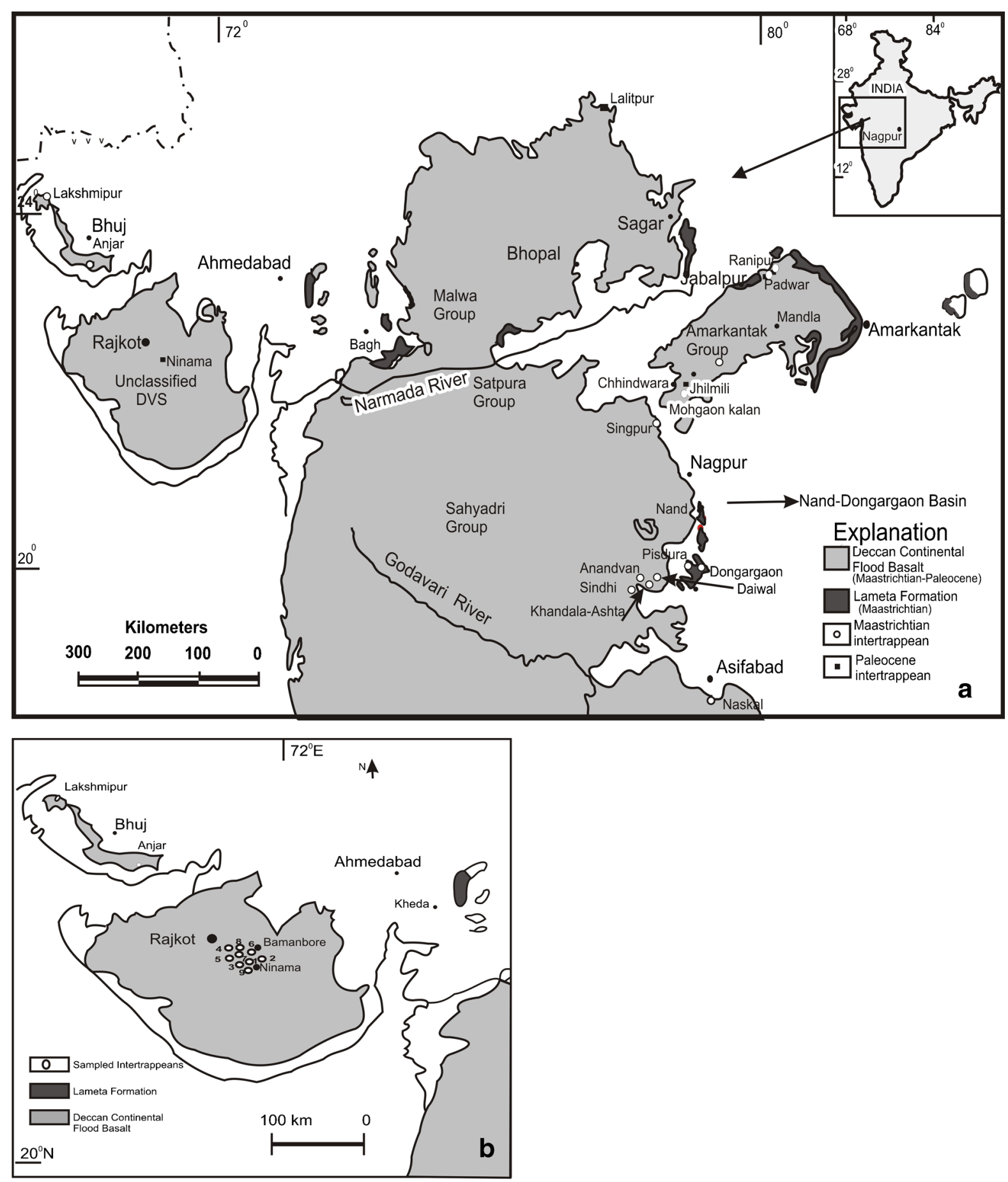

1.Ninama Hill section 2. Ninama river section 3. Gangajal-Goraiya section

4. Vasundhara road section 5. Vasundhara juna section 6.Bamanbore section

7. Bamanbore-Nawargaon section 8. Wakaner-Bamanbore section 9. Jalsika

road section

Figure 1. (a) Map showing important intertrappean localities in DCFB province and their age. (b) Map showing studied intertrappean localities in Saurashtra, Gujarat.

Out of the studied nine intertrappean sections only Ninama Hill section has yielded palynomorphs. In this section, well preserved pollen and spores and a good concentration of biodegraded organic matter was recovered from the uppermost $2 \mathrm{~cm}$ thick chert band. A few sponge spicules were also recovered from the shales overlying the chert band. Except for Ninama Hill section, other sections did not yield palynomorphs. However, scales of fishes (Clupids), gastropods and ostracods were recorded from the Ninama Hill section and Jalsika Road section. 
Table 1. Studied intertrappean section at Saurashtra.

\begin{tabular}{llll}
\hline Sl. no & \multicolumn{1}{c}{ Locality } & \multicolumn{1}{c}{$\begin{array}{c}\text { Co-ordinates } \\
\text { Elevation } \\
(\mathrm{m})\end{array}$} \\
\hline 1 & Bamanbore-Wakaner New Road section & $22^{\circ} 28^{\prime} 47^{\prime \prime} \mathrm{N}$ and $71^{\circ} 02^{\prime} 40^{\prime \prime} \mathrm{E}$ & 184 \\
2 & Ninama Hill & $22^{\circ} 18^{\prime} 15^{\prime \prime} \mathrm{N}$ and $71^{\circ} 19^{\prime} 52^{\prime \prime} \mathrm{E}$ & 181 \\
3 & Ninama River section & $22^{\circ} 18^{\prime} 00^{\prime \prime} \mathrm{N}$ and $71^{\circ} 20^{\prime} 06^{\prime \prime} \mathrm{E}$ & 181 \\
4 & Vasundhara Road section & $22^{\circ} 27^{\prime} 38^{\prime \prime} \mathrm{N}$ and $71^{\circ} 01^{\prime} 28^{\prime \prime} \mathrm{E}$ & 180 \\
5 & Bamanbore-Navagam section & $22^{\circ} 24^{\prime} 58^{\prime \prime} \mathrm{N}$ and $71^{\circ} 03^{\prime} 02^{\prime \prime} \mathrm{E}$ & 180 \\
6 & Bamanbore Section (old) & $22^{\circ} 28^{\prime} 37^{\prime \prime} \mathrm{N}$ and $71^{\circ} 02^{\prime} 58^{\prime \prime} \mathrm{E}$ & $22^{\circ} 15^{\prime} 27^{\prime \prime} \mathrm{N}$ and $71^{\circ} 23^{\prime} 49^{\prime \prime} \mathrm{E}$ \\
7 & Gangajal-Goraiya Road section & $22^{\circ} 27^{\prime} 04^{\prime \prime} \mathrm{N}$ and $71^{\circ} 00^{\prime} 49^{\prime \prime} \mathrm{E}$ & 163 \\
8 & Vasundhara-Juna section & $22^{\circ} 29^{\prime} 20^{\prime \prime} \mathrm{N}$ and $70^{\circ} 58^{\prime} 10^{\prime \prime} \mathrm{E}$ & 158 \\
9 & Jalsika Road section & &
\end{tabular}

\section{Materials and methods}

For palynological and clay mineralogical studies, the samples were drawn from different lithounits of all the nine sections (figure 2). About 50 samples were macerated from different sections (figure 2). Depending on the rock types the samples were given standard chemical treatment $(\mathrm{HCl}$, $\mathrm{HF}, \mathrm{HNO}_{3}$ and $\mathrm{KOH}$ ) to liberate the organic matter from the rock and to concentrate the palynoassemblage. After chemical treatment, samples were sieved using $150 \mu \mathrm{m}$ sieves and slides were prepared using polyvinyl alcohol and Canada balsam. Optical study of the slides was carried out using Olympus BX51 microscope. All the holotype slides and the slides from which photographs are taken (Plate 1,2) are housed in the museum of PG Department of Geology, RTM Nagpur University, Nagpur. The reference of slides in the text is given as slide numbers and England Finder reading.

For clay mineralogical studies finely powdered samples of the sediments were fractionated for total clay $(<2 \mu \mathrm{m})$ and fine clay $(<0.2 \mu \mathrm{m})$ after dispersion using sodium carbonate following size segregation procedure of Jackson (1979). Oriented clay factions of total clay and fine clay were subjected to X-ray diffraction (XRD) analysis using a Philips diffractometer and Nifiltered $\mathrm{CuK} \alpha$ radiation at a scanning speed of $2^{\circ} 2 \theta / \mathrm{min}$. The samples were saturated with $\mathrm{Ca}$ and $\mathrm{K}$, solvated with ethylene glycol, and heated to $110^{\circ}, 300^{\circ}$, and $550^{\circ} \mathrm{C}$. The identification of clay minerals was done following the criteria of Jackson (1979). Semi-quantitative estimates of the clay minerals were made following the principles outlined by Gjems (1967) and Kapoor (1972).

\section{Systematics of palynomorphs and age}

Detailed palynological study of the Ninama intertrappean shows presence of pollen and spore assemblage which can be placed into 12 genera and 14 species. The quantitative analysis of the samples shows less diversity in palynotaxa and dominance of genus Neocouperipollis (table 2). The assemblage comprises spore of pteridophytes such as Pteridacidites sp., pollen of gymnosperm taxa Araucariacites and angiosperm taxa Aquilapollenites bengalensis, Aquilapollenites ovatus, Aquilapollenites sp., Arecipites communis, Crototricolpites densus, Liliacidites sp., Neocouperipollis sp. Retitricolpites crassimarginatus, Retitricolporites sp., Rhombipollis sp., Striacolporites striatus, Proteacidites sp., Intrareticulites brevis and Typha like pollen. In addition, fungi Frasnacritetrus sp., algae Pediastrum sp. and a sole dinoflagellate cyst have also been recovered from these sediments. One new species has been erected based on its distinct morphological characters. Photographs of the important pollen are given in plates 1 and 2 .

Genus: Crototricolpites Leidelmayer (1966)

Type species: Crototricolpites annemariae Leidelmayer (1966)

Crototricolpites densus Salard Cheboldaeff (1978)

Plate 2, figures 7, 8, 11, 12

No. of specimen studied: Three complete and three broken specimens.

Measurements: $38-45 \times 22-32 \mu \mathrm{m}$ in size

Remarks: In overall morphology, the specimen recovered from the Ninama intertrappean sediments shows similarity with the $C$. densus Salard Cheboldaeff (1978) recorded by Rao and Ramanujam (1982) from the Quilon beds of Kerala however, the specimens recorded from the Ninama have some minor morphological differences from the specimen recorded from Quilon beds. The Ninama specimens have thick margined colpi and slightly thin exine $(2 \mu \mathrm{m})$ in comparison with the Quilon specimen that has 2.5-3.5 $\mu \mathrm{m}$ thick exine. The clavae of the Quilon specimen are also slightly longer $(1.2-2.5 \mu \mathrm{m}$ long) than that of Ninama specimens $(0.5 \mu \mathrm{m}$ long). 


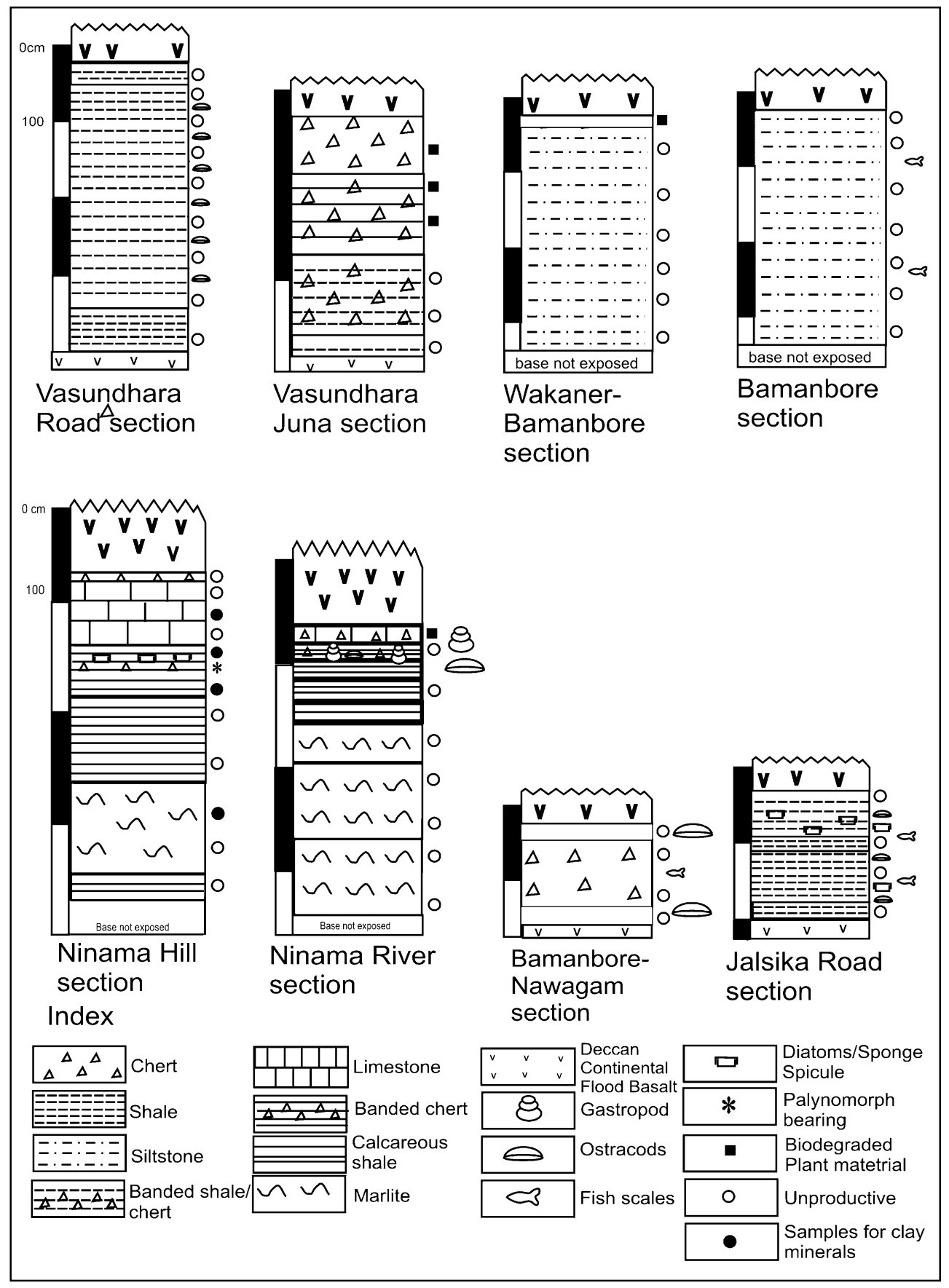

Figure 2. Lithosections of the studies - intertrappean sections in Saurashtra.

Affinity: Possibly Drypterocarpaceae

Genus: Neocouperipollis Kar and Kumar (1987)

Type species: Neocouperipollis kutchensis

(Venkatachala and Kar) Kar and Kumar (1987)

Neocouperipollis deccanii n.sp

Plate 1, figures 1-4, 6, 12

Etymology: After its recovery from the Deccan volcanic associated sediments.

Holotype: Plate 1, figure 4; PGNUDI, 2S; NM 1, 20; W-52/2; Black Chert in Ninama Hill section.

No. of specimens studied: 20
Diagnosis: Pollen oval to spherical in shape; monosulcate, sulcus long, and sometime extending more than two third of the grain; spinose ornamentation. Description: Pollen grains oval to spherical in shape; monosulcate, sulcus long, end to end and sometimes extending more than two third of the grain, sulcus margins thin, irregular, open or closed, spines present at the colpi margins; exine thin, sexine and nexine not differentiable; ornamentation spinose, spines 1-2 $\mu \mathrm{m}$, spines sparsely distributed, shape of spines variable, 
Table 2. Concentration of palynomorphs in the Ninama intertrappean sediments.

\begin{tabular}{lr}
\hline & Pollen \\
Taxa & count \\
\hline Pediastrum boryanum & 4 \\
Frasnacritetrus sp. & 1 \\
Dinoflagellate & 1 \\
Fungal spores & 17 \\
Pteridacidites sp. & 1 \\
Aquilapollenites bengalensis & 1 \\
A. ovatus & 4 \\
A. sp. & 1 \\
Arecipites communis & 1 \\
Araucariacites sp. & 2 \\
Crototricolpites densus & 5 \\
Graminidites sp. & 1 \\
Liliacidites sp. & 1 \\
Intrareticulite brevis & 1 \\
Neocouperipollis deccanii & 132 \\
Retitricolpites crassimarginatus & 1 \\
Retitricolpites sp. & 1 \\
Rhombipollis sp. & 200 \\
Striacolporites striatus & 1 \\
Proteacidites sp. & 7 \\
Triporopollenites indicus & 4 \\
Typha like pollen & 2 \\
Total & 8 \\
\hline & 3 \\
& \\
&
\end{tabular}

spines with bulbous base or clavate, end of spines blunt to pointed, spines at the colpal margins slightly smaller than at other places, interspinal area smooth to infrasculptured.

Measurements: Size range of $42-45 \times 21-34 \mu \mathrm{m}$ is common in oval forms, size range of $30-40 \mu \mathrm{m}$ in spheroidal forms.

Remarks: The proposed species differ from $N$. kutchensis Kar and Kumar (1987) in having sparsely distributed short spines. N. magnus Kar and Kumar (1987) and N. spinulatus Kar and Kumar (1987) are very large in size. N. spinulatus Kar and Kumar (1987) has granulose interspinal area. N. brevispinosus (Venkatachala and Kar) Sarkar and Singh (1988) is large in size with closely placed spines and granulose interspinal area and N. capitatus Sarkar and Singh (1988) has pear-shaped spine and granulose interspinal area. Affinity: Possibly with Arecaceae genus Pinanga. Genus: Aquilapollenites (Rouse) Srivastava (1968) Type species: Aquilapollenites quadrilobatus (Rouse) Srivastava (1968)

Aquilapollenites ovatus Hofmann and Zetter (2007) Plate 2, figures 9 and 10

Remarks: In overall shape, size and wedge like projections at the equatorial region the palynomorphs of $A$. ovatus from the Ninama are similar to that of the forms recorded from the Upper Cretaceous sediments of Siberia (Hofmann and Zetter 2007). The Siberia specimens have characteristic small granule like spines whereas the Ninama specimens have very small granules on the surface.

Affinity: unknown

Age: The Ninama assemblage has a Paleocene taxa such as Intrareticulites brevis, Neocouperipollis spp., Striacolporites striatus, Retitricolporites crassimarginatus and Rhombipollis sp. These taxa have so far been recorded from the Paleocene or Early Eocene deposits of India (Saxena 1990; Frederiksen 1994). Significantly, characteristic Maastrichtian palynoassemblage such as Azolla cretacea, Gabonisporis vigourouxii, Triporoletes reticulatus and Normapolles group pollen is not recorded from this intertrappean. Thus, on the basis of palynoassemblage and overall age of the Deccan volcanism (Late Cretaceous-Early Paleocene, 67-63 My) (Venkatesan et al. 1993, 1996; Channet et al. 2008; Jay and Widdowson 2008; Jay et al. 2009), a Paleocene age is indicated for the Ninama intertrappean sediments.

\section{Clay mineral assemblages in sediments of Ninama Hill section}

The clay mineral investigation of carbonate shale, marl, chert, and limestone of the Ninama Hill section shows presence of mica, smectite, vermiculite, kaolin, quartz, and feldspar in fine clay fraction of the sediments. A semi-quantitative estimate and paleoenvironmental significance is summarized in table 3 and figure 3 . The XRD characteristic of the fine clay fraction $(<0.2 \mu \mathrm{m})$ shows following clay minerals. Smectite (Sm): Peak at $1.7 \mathrm{~nm}$ on glycolation, shifts to $1.1-1.2 \mathrm{~nm}$ on K-saturation and heating to $110^{\circ} \mathrm{C}$. This is a low charge smectite formed due to weathering of feldspar (Harward et al. 1969; Pal et al. 1989, 2012). Vermiculite $(\mathrm{Vm})$ : peak at $1.4 \mathrm{~nm}$ on glycolation which decreases on heating the K-saturated samples with concurrent increase of $1.0 \mathrm{~nm}$ peak of mica (Schultz et al. 1971). This is considered as weathering product of biotite under arid conditions (Pal et al. 1989; Srivastava et al. 1998). Mica (biotite/muscovite): characteristic peak at $1.0 \mathrm{~nm}$, not affected by heating or glyocolation; the ratio of 001/002 peak is typically $>1$ (range $3.2-4.3$ ) indicating both biotite and muscovite in mica fraction. Increase of the 001/002 ratio from 3.2 to 4.3 suggests increase of biotite content and possible changes of flux through more mafic source rock. Kaolin: characteristic peak at $0.7 \mathrm{~nm}$, no shifting on glycolation and heating $\mathrm{K}$-saturated samples to $300^{\circ} \mathrm{C}$ but on heating up to $550^{\circ} \mathrm{C}, 1.0 \mathrm{~nm}$ peak gets reinforced. Feldspar (F): characteristic peaks at 0.318, 0.403, 

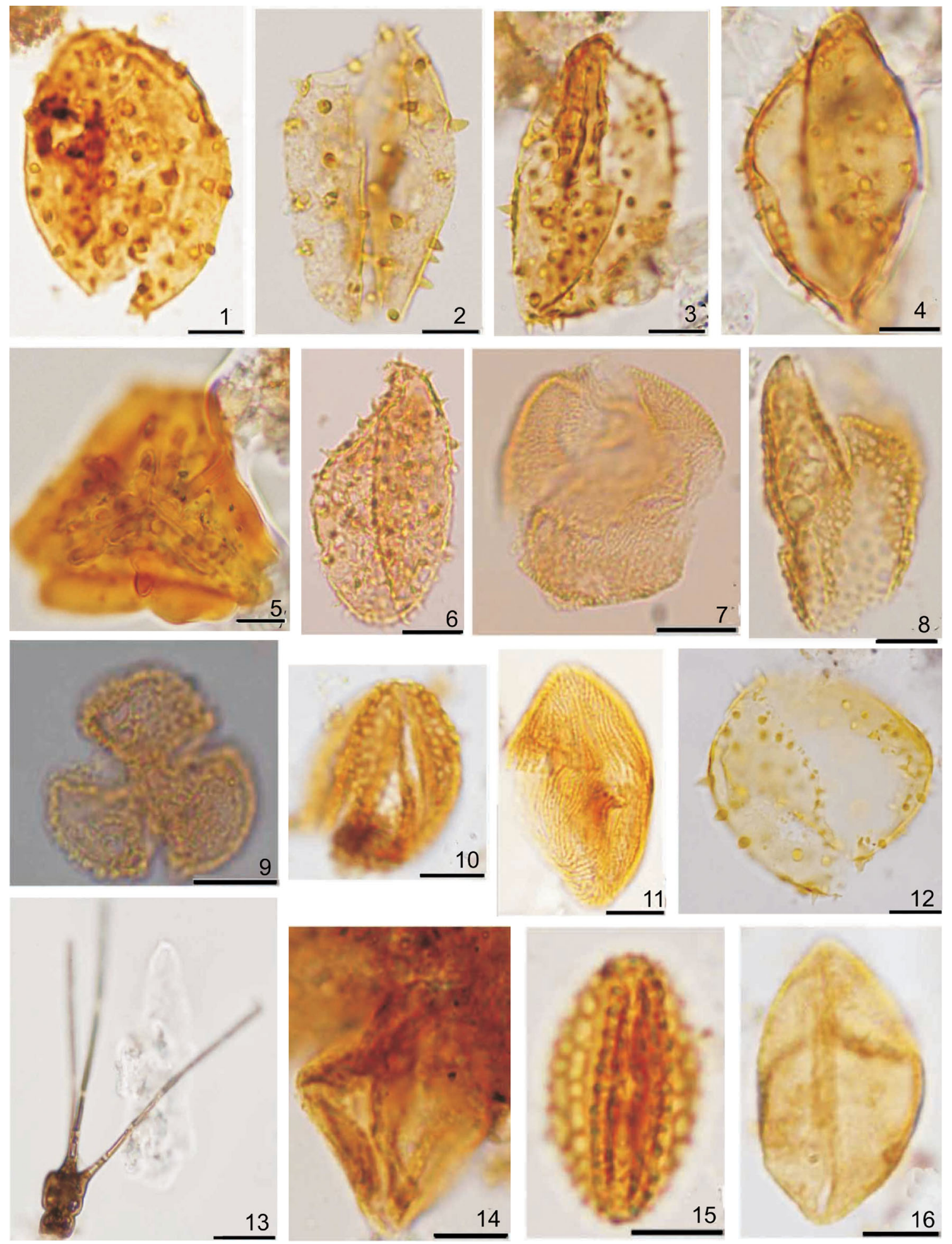

13
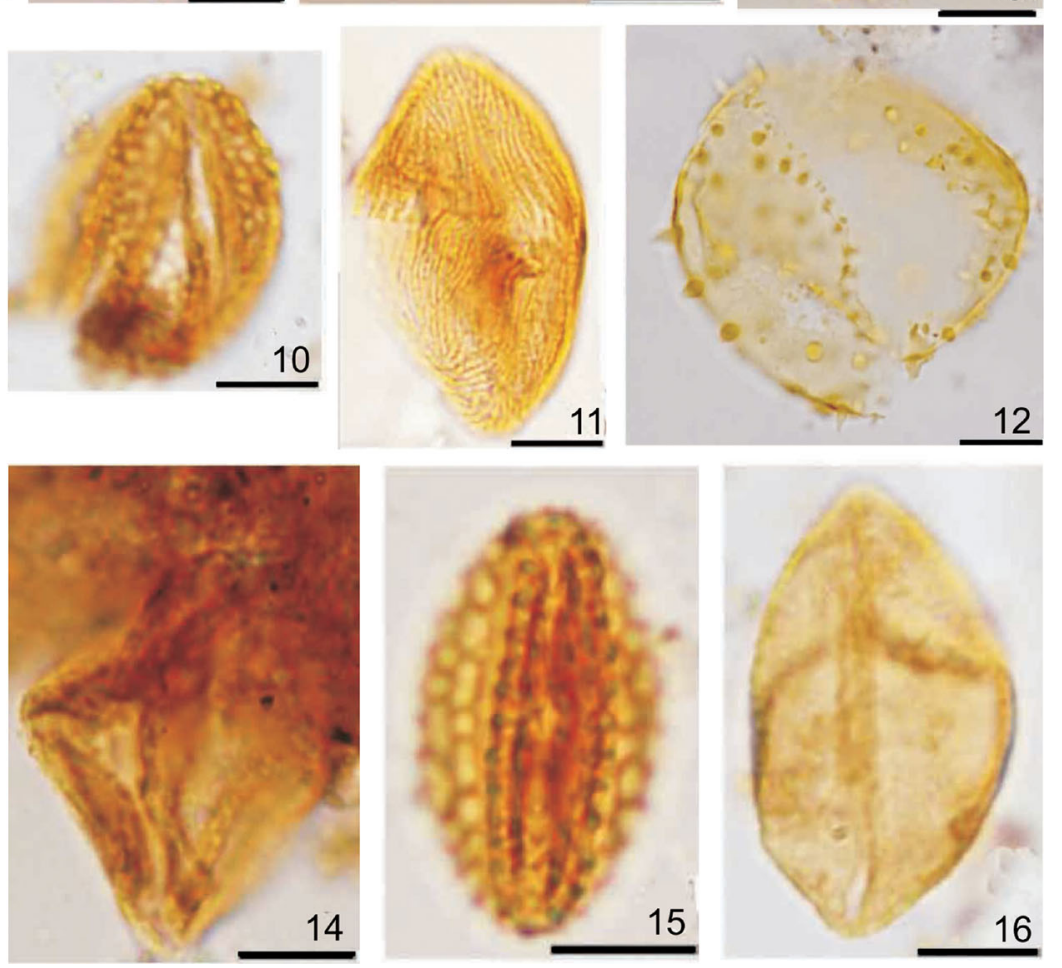

Plate 1. (1-4, 6, 12) Neocouperipollis deccanii sp. nov. (1) Slide NM 1, 6; EF Z-52/2. (2) Slide NM 1, 8; EF R-30. (3) Slide NM 1,16, 5; EF O-48. (4) Slide NM 1, 20; EF-W-52/2. (6) Slide NM B1; EF O-54. (12) Slide NM 1, 1; EF-Y-52. (5) Pteridacidites sp. Slide NM 1, 8; EF-K48. (7) Striacolporites striatus in polar view. Slide NM 1B, 4 ; EF-X34. (8) Liliacidites sp. Slide NM 1, 15; EF-R45. (9) Intrareticulites brevis (Sah and Kar) Kar 1985. Slide NM B1, 7; EF-K38/2. (10) Retitricolpites crassireticulatus (Dutta and Sah) Samant and Phadtare 1997 Slide NM 1, 6; EF-V-45/3. (11) Striacolporites striatus Sah and Kar 1970 Equatorial view. Slide NM 1, 10; EF-L29/1. (13) Frasnatetradites sp. Slide NM 1, 10; EF-49/3. (14) Rhombopollis sp. A Slide NM 1, 16; EF-L-32. (15) Retitricolporites sp. A Slide NM 1, 20; EF-Q30/2. (16) Arecipites communis Mathur and Chopra 1987. Slide NM 1, 4; EF-N44. Scale bar represents 10 micron and EF is England finder reading. 

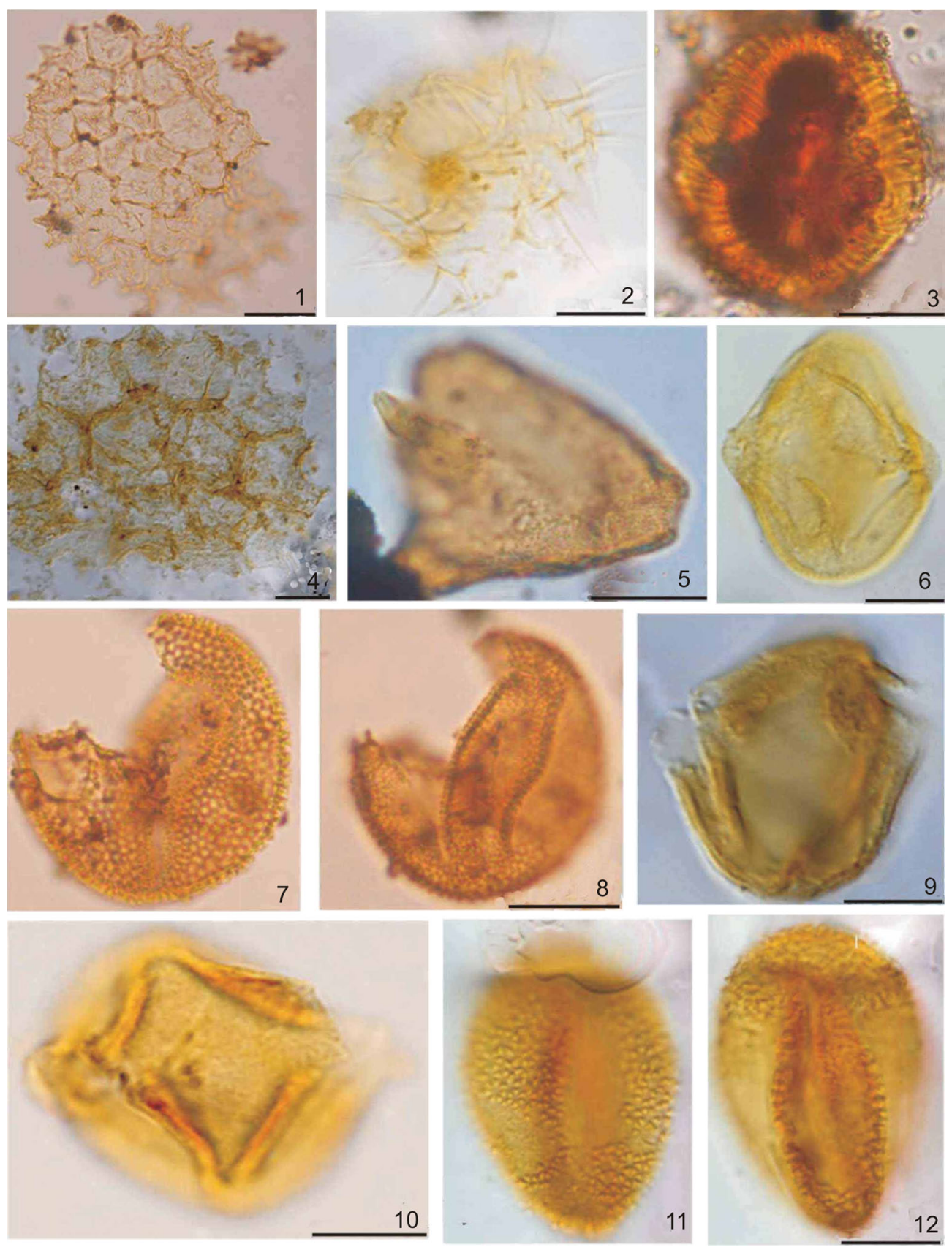

Plate 2. (1, 4) Pediastrum boryanum Maneghini (1) Slide NM 1B, 2; EF-K53, (4) Slide NM 1, 4; EF-P51. (2) Dinoflagellate Slide NM 1A; EF-D39. (3) Aquilapollenites bengalensis Baksi and Deb 1976. Slide NM 4, w1; EF-N41. (5) Proteacidites sp. A Slide NM B1, 13; EF-K32/4. (6) Aquilapollenites sp. A. Slide NM 1B,10; EF-P36. (7, 8) Crotonipollis densus Salard Cheboldaeff 1978. Slide NM 13, 6 ; EF-W60/3. (9 and 10) Aquilapollenites ovatus Hoffman and Zetter, 2007. (9) Slide NM 1, 10; EF-O60, (10) Slide NM 1B, 4; EF-T40/3. (11, 12) Crotonipollis densus Salard Cheboldaeff 1978 Slide NM 1, A; $\mathrm{EF}-\mathrm{V} 63 / 3$.

and $0.32 \mathrm{~nm}$, Quartz $(\mathrm{Q})$ : characteristic peaks at 0.334 and $0.426 \mathrm{~nm}$.

\section{Correlation and depositional environments}

In comparison to diverse flora and fauna from the intertrappean sediments of central and southern
India (summarized by Khosla and Sahni 2003), their record from the intertrappean deposits of western India is scanty. From the northwestern DCFB sequence of Kutch, the biota is so far known only from three intertrappean localities, namely Anjar, Lakshmipur and Dayapar sediments. Of these, the Anjar intertrappean sediments have drawn special attention for its high Ir anomaly and abundant fossils including 
Table 3. Clay mineral assemblage in sediments of Ninama Hill section and its paleoenvironmental significance.

\begin{tabular}{|c|c|c|c|c|c|c|c|c|c|}
\hline \multicolumn{2}{|c|}{ S. N lithology } & \multirow{2}{*}{$\begin{array}{c}\mathrm{Sm} \\
(\%) \\
3\end{array}$} & \multirow{2}{*}{$\begin{array}{r}\mathrm{Vm} \\
(\%) \\
16\end{array}$} & \multirow{2}{*}{$\begin{array}{c}\text { Mica } \\
(\%) \\
49\end{array}$} & \multirow{2}{*}{$\begin{array}{c}\mathrm{Ka} \\
(\%) \\
7\end{array}$} & \multirow{2}{*}{$\begin{array}{c}\mathrm{Q} \\
(\%) \\
1\end{array}$} & \multirow{2}{*}{$\begin{array}{c}\mathrm{F} \\
(\%) \\
21\end{array}$} & \multirow{2}{*}{$\begin{array}{c}001 / 002 \\
4.3\end{array}$} & \multirow{2}{*}{$\begin{array}{l}\text { Remarks } \\
\text { Large amount of biotite, mica and } \\
\text { vermiculite suggest weathering of } \\
\text { biotite in arid climate in source } \\
\text { area and change to mafic rich } \\
\text { detrital flux }\end{array}$} \\
\hline 4 & Limestone & & & & & & & & \\
\hline 3 & $\begin{array}{l}\text { Calcareous shale/ } \\
\text { banded chert }\end{array}$ & 65 & 10 & 10 & 1 & 1 & 12 & 4.0 & $\begin{array}{l}\text { Dominance smectite (LCS) after } \\
\text { feldspar and vermiculite after } \\
\text { biotite indicate weathering in } \\
\text { arid climate in source area }\end{array}$ \\
\hline 2 & Calcareous shale & 86 & - & 7 & 1 & 1 & 5 & 3.4 & $\begin{array}{l}\text { Dominance of smectite (low charge } \\
\text { smectite-LCS) suggest weathering of } \\
\text { feldspar in arid climate in source area }\end{array}$ \\
\hline 1 & Marlite & 71 & - & 12 & 3 & 3 & 9 & 3.2 & $\begin{array}{l}\text { Dominance of smectite (low charge } \\
\text { smectite-LCS) suggest weathering of } \\
\text { feldspar in arid climate in source area }\end{array}$ \\
\hline
\end{tabular}

titanosauriform dinosaur bones, eggshells, molluscs, ostracods and angiosperm fossils woods. Based on palynoassemblage, magnetostratigraphic studies and radiometric dating a Maastrichtian age (chron 29R) is suggested for the Anjar sediments (Bhandari et al. 1996; Bajpai and Prasad 2000; Hansen et al. 2001, 2005; Dogra et al. 2004). The Lakshmipur intertrappean bed has well preserved ostracods (Whatley and Bajpai 2000), molluscs, and palynomorphs (Samant and Bajpai 2005). The palynoassemblage, viz., Contignisporites sp., Retitricolpites vulgaris, Proxapertites spp. Aquilapollenites bengalensis suggested an Early Maastrichtian age for the deposits (Samant and Bajpai 2005). From the Dayapar intertrappean beds fragmentary dinosaur bones and the ostracod fauna is known (Whatley and Bajpai 2000). The palynoflora of the Ninama has a noticeable presence of Paleocene marker palynomorphs whereas the palynoassemblage of the sediments of Lakshmipur and Anjar are characterized by Maastrichtian palynomorphs.

From the southwestern part of DCFB sequence around Mumbai many intertrappean deposits are known with diverse faunal remains (Khosla and Sahni 2003; Cripps et al. 2005) and scanty floral record (both mega and microflora). The flows in this area are assigned Paleocene age based on ${ }^{40} \mathrm{Ar} /{ }^{39} \mathrm{Ar}$ isotope study (Widdowson et al. 2000; Sheth et al. 2001a, b; Cripps et al. 2005). The new finding of palynomorph bearing intertrappean from the Saurashtra is significant as it has helped in bridging the gap in our knowledge of floral composition of widely separated intertrappean localities of the northwestern and southwestern DCFB provinces.
The correlation of palynoflora of Ninama intertrappean with that of intertrappean deposits of Sahyadri and Amarkantak groups of central and southern India suggests that Ninama has a characteristic Paleocene palynoassemblage whereas other intertrappean deposits have Maastrichtian palynomorphs such as Azolla cretacea, Gabonisporis vigourouxii, Triporoletes reticulatus and Normapolles group pollen (summarized in Samant and Mohabey 2009).

The Ninama assemblage is also different from the only other known Paleocene intertrappean sediments of Lalitpur in Uttar Pradesh (figure 1). This intertrappean has Paleocene forms such as Dandotiaspora spp., Matanomadhiasulcites and Lakiapollis ovatus (Singh and Kar 2003). Such forms are not recorded from the Ninama section. This difference in floral composition might be due to difference in depositional conditions. The Ninama assemblage has both near marine taxa (Neocouperipollis, Palm) as well as fresh water taxa such as Pediastrum and Typha like pollen which suggest deposition in mixed (estuarine to near marine) environmental conditions.

In the Ninama Hill section (figure 2), except thin chert band, other samples are mostly carbonate dominating (marlite and calcareous shale and limestone) which are either barren of palynomorphs or contain only a few chlamydospores of mycorrhizal fungi and biodegraded organic matter. Lithology and clay mineralogy of the samples (figure 2) of this section suggests deposition in alkaline conditions possibly due to excessive evaporative conditions and prevalence of arid climatic conditions. The study also shows that except for Ninama, all the other intertrappean deposits in the study area 


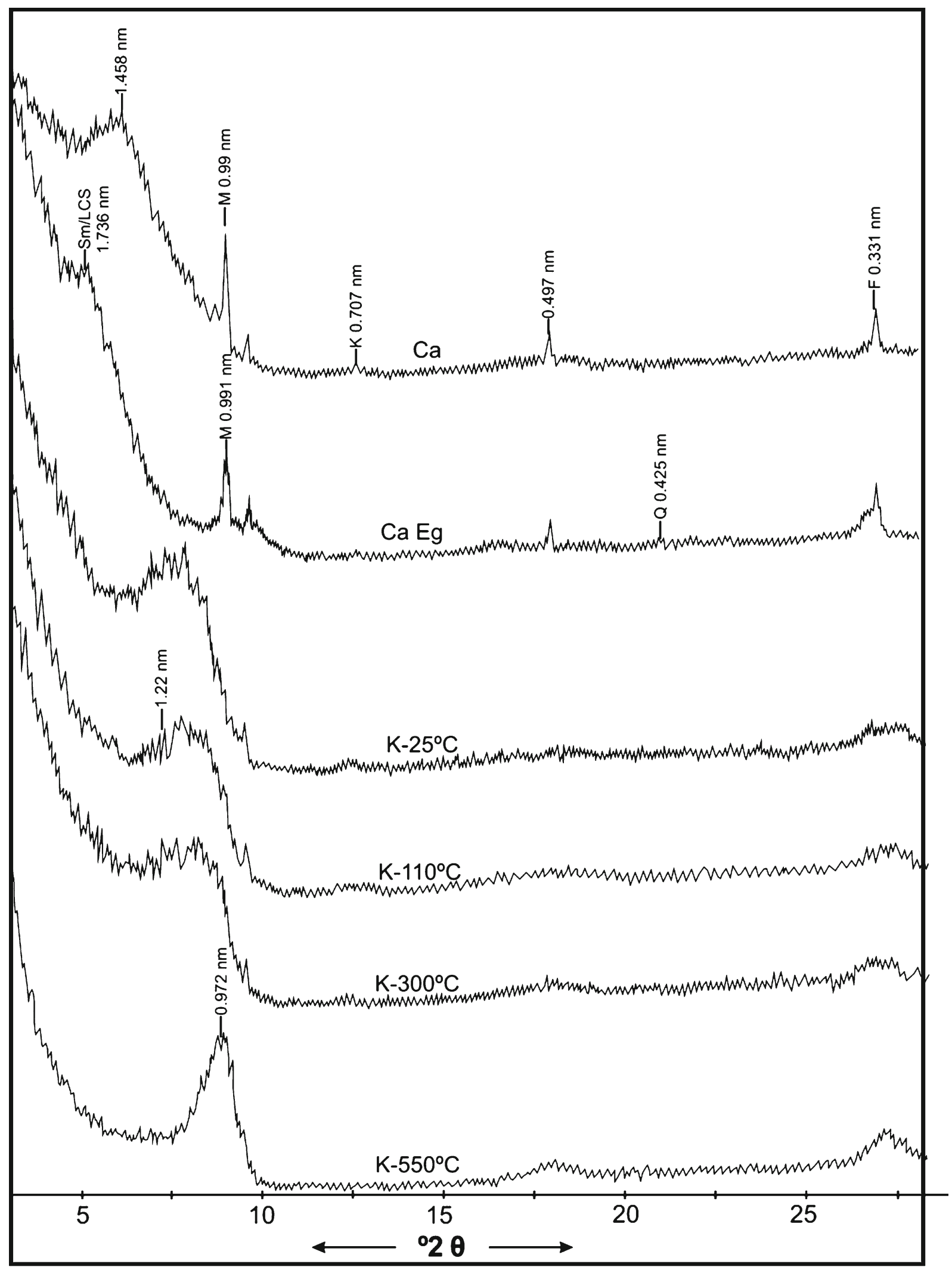

Ninama Hill Section, Fine Clay fraction $(<0.02 \mu \mathrm{m})$; Ca-Ca saturated, CaEg-Ca saturated and glycolated; $\mathrm{K}-25^{\circ} \mathrm{C}, \mathrm{K}-110^{\circ} \mathrm{C}, \mathrm{K}-300^{\circ} \mathrm{C}, \mathrm{K}-550^{\circ} \mathrm{C}, \mathrm{K}$-saturated and heated, Sm-Smectite, LCS-Low Charge Smectite, M-Mica, Q-Quarz, F-Feldspar. 
are either barren of palynomorphs or contain only biodegraded organic matter such as hard woody tissues, trachieds, vessels and mycorrhizal fungi. The presence of biodegraded organic matter in the intertrappean sediments could be due to low vegetation growth, highly oxygenated depositional condition and unfavourable conditions for their preservation because of arid climatic conditions.

\section{Discussion}

Presently it is considered that the northward moving Indian plate over the reunion hotspot has emplaced the earliest lava flows of DCFB in the Saurashtra-Kutch province with the eruptive centers gradually shifting southwards (Widdowson et al. 2000). In this context, the present finding of the presence of marker Paleocene palynoflora in the intertrappean sediments of Ninama becomes crucial as it suggests that the associated lava flows above the sediments are of Paleocene age. Implicitly, the Saurashtra region continued to witness the eruption of Deccan flood basalts even during the Paleocene.

The clay mineral assemblage in sediments of the Ninama Hill section shows dominance of smectite up to $86 \%$ along with presence of mica, vermiculite, and kaolin. Clay mineral variation from lower to upper part of the section is marked by increase of mica and vermiculite (table 3 ). The smectite described here is low charge smectite (LCS) derived from the weathering of feldspar (Harward et al. 1969). The large amount of the LCS in sediments is indicative of arid climatic conditions (Pal et al. 1989, 2012). Presence of vermiculite along with an increase of biotite in mica fraction is also indicative of biotite weathering in arid conditions (Srivastava et al. 1998). This is also suggestive of a change in sedimentary flux to biotite rich source rock when compared with source for smectite dominated flux. The clay minerals also suggest presence of mafic/ultrabasic rocks in the provenance during deposition of Ninama intertrappean sediments. The presence of vermiculite is in agreement with alteration of mafic minerals (Adams 1976; Adams and Kassim 1983). The clay mineral assemblages in the intertrappean sediments from Ninama Hill section suggest prevalence of arid climatic conditions during the sedimentation except for a short warm humid spell when the palynomorphs rich chert was deposited. The clay mineral assemblage recorded in Ninama sediments is in accord with global record of smectite peak during 67-65 Ma from $\mathrm{K}-\mathrm{T}$ boundary sections indicating extreme climatic conditions (Li and Keller 1998; Zachos et al. 2001; Adatte et al. 2002).
The prevalence of arid climate and highly alkaline conditions during the deposition of sediments associated with the upper part of Sahyadri Group, possibly close to the K-Pg boundary have also been indicated (Samant et al., Comm.). The intertrappean sediments in this part are also dominated by carbonates and contain mostly biodegraded plant material. From the Amarkantak Group of Chhindwara area in central India, the Jhilmili intertrappean has yielded planktic foraminifera of P1a zone which indicate deposition of the sediments in early Danian. Clay mineralogy of this $14 \mathrm{~m}$ thick intertrappean section indicated that the major part of this intertrappean has been deposited in arid environments (Keller et al. 2009). The available data and present study from the widely separated intertrappean deposits of Saurashtra and Kutch of western India, Sahyadri and Amarkantak groups of central India, indicate prevalence of local volcanogenic induced arid ('mock aridity') conditions close to the $\mathrm{K}-\mathrm{Pg}$ boundary (Khadkikar et al. 1999; Keller et al. 2009) in the DCFB province. Away from this province, humid to sub-humid conditions prevailed in the northeast as recorded from the marine section of Meghalaya (Gertsch et al. 2011). In other parts of the world like Tunisia, Kazakistan and South Atlantic (Adatte et al. 2009) humid subhumid climatic conditions have prevailed close to the $\mathrm{K}-\mathrm{Pg}$ boundary. Similarly coal band occurs in parts of western interior of North America close to boundary clay in Paleocene and Cretaceous (viz., Montana, North Dakota, Raton basin). General increase in precipitation pattern has also been observed in North America close to K-Pg B (Retallack et al. 1987; Boulter et al. 1988; Spicer 1989). In the DCFB province humid to sub-humid conditions appeared in the waning phase of volcanism which is indicated by the presence of rich and diversified palynoflora in the associated sediments higher-up in the DCFB sequences (Samant et al., Comm.) and also development of laterite and bauxite profiles over the volcanic flows (Devaraju and Khanadali 1993; Retallack 2010).

\section{Conclusion}

Study of nine sections of the intertrappean sediments of Saurashtra area was carried to know the palynomorphs assemblage in the area. Of these sections, only the intertrappean sediments at Ninama yielded palynoassemblage of Paleocene age. Palynological assemblage together with clay mineralogy of the sediments suggests prevalence of arid climatic conditions during the deposition of intertrappean sediments. The correlation of palynological data and clay mineralogy of intertrappean 
deposits of Saurashtra area with that of intertrappean deposits of Amarkantak and Sahyadri groups of central India suggests extreme climatic conditions marked by aridity during Late Maastrichtian and Early Paleocene.

\section{Acknowledgements}

The authors are thankful to the reviewers and the editor for critical but constructive comments that helped to revise an earlier version of the manuscript. BS is thankful to the Council of Scientific and Industrial Research, New Delhi (Grant No. 24/297/08-EMR-II) and SAP-DRS-I for financial assistance. They are also thankful to Head, PG Department of Geology, Rashtrasant Tukadoji Maharaj Nagpur University, Nagpur for providing working facility. The authors are thankful to the Director General, Geological Survey of India for technical co-operation and permission to publish the paper. The findings have been made under a joint collaborative programme under MOU involving GSI, Central Region, Nagpur and RTM Nagpur University.

\section{References}

Adams W A 1976 Experimental evidence on the origin of vermiculite in soils on Lower Palaeozoic sediments; Soil Sci. Soc. Am. J. 40 793-796.

Adams W A and Kassim J K 1983 The origin of vermiculite in soils developed from Lower Palaeozoic sedimentary rocks in Mid-Wales; Soil Sci. Soc. Am. J. 47 316-320.

Adatte T, Keller G, Gerstch B, Gardin S, Bartolini A and Bajpai S 2009 Paleoenvironmental changes linked to Deccan volcanism and $\mathrm{K}-\mathrm{T}$ mass extinction across India and their correlation with more distant area; Geophys. Res. Abstr. 112517.

Adatte T, Keller G, Burns S, Stoykova K H, Ivanov M I, Vangelov D, Kramar U and Stuben D 2002 Paleoenvironments across the Cretaceous-Tertiary transition in eastern Bulgaria; In: Catastrophic events and mass extinctions: Impacts and Beyond, Boulder (eds) Koeberi C and Macleod K G, Colorado, Geol. Soc. Am. Spec. Paper 356 231-251.

Auden J B 1999 Dykes in western India - a discussion of their relationship with the Deccan Traps (reprinted from Trans. Nat. Soc. India, III(3), 1949); Geol. Soc. India Memoir. 43 277-318.

Bajpai S and Prasad G V R 2000 Cretaceous age for Ir-rich Deccan Intertrappean deposits: Paleontological evidence from Anjar, western India; J. Geol. Soc. London $157257-$ 260.

Baksi S K and Deb U 1976 On new occurrence of Aquilapollenites from eastern India; Pollen et Spores 18(3) 399-406.

Beane J E, Turner C A, Hooper P R, Subbarao K V and Walsh J N 1986 Stratigraphy, composition and form of the Deccan basalt, Western Ghats, India; Bull. Volcanol. 48 61-83.

Bhandari N, Ghevariya Z G and Sunderam S M 1996 Impact did not trigger Deccan volcanism: Evidence from Anjar
K/T boundary intertrappean sediments; Geophys. Res. Lett. 22 433-436.

Biswas S K and Deshpande S V 1983 Geology and hydrocarbon prospects of Kutch, Saurashtra, and Narmada basin; Petrol. Asia J. 6 111-126.

Boulter M C, Spicer R A and Thomus B A 1988 Pattern of plant extinction from some paleobotanical evidences in extinction and survival in the fossil record (ed.) Larwood G P, Systematic Association Special Volume, (Oxford: Clarendon Press), 34 1-36.

Borkar V D 1973 New fossil fishes from the intertrappean beds in Surendranagar District, Gujarat; Curr. Sci. 42(12) 422-423.

Borkar V D 1986 Fossil fish scales from intertrappean beds at Ninama, District Surendranagar, Gujarat; Biovigyanum 12(1) $63-67$.

Channet A L, Fluteau F, Courtillot V, Gerard M and Subbarao K V 2008 Determination of rapid eruption across the KTB using palaeomagnetic secular variation: (I) results from a $1200 \mathrm{~m}$ thick section of the Mahabaleshwar escarpment; J. Geophys. Res. 113 B04101.

Cox K G and Hawkesworth C J 1984 Relative contribution of crest and mantle to flood basalt magmatism, Mahabaleshwar area, Deccan Traps; Phil. Trans. Roy. Soc. London $310627-641$.

Courtillot V, Besse J, Vandamme D, Montigny R, Jaeger J J and Cappetta H 1986 Deccan flood basalt at the Cretaceous $\backslash$ Tertiary boundary; Earth Planet. Sci. Lett. $80361-374$.

Cripps J A, Widdowson M, Spicer R A and Jolley D W 2005 Coastal ecosystem response to late stage Deccan trap volcanism: The post $\mathrm{K}-\mathrm{T}$ boundary (Danian) palynofacies of Mumbai (Bombay), west India; Palaeogeogr. Palaeoclimatol. Palaeoecol. 216 303-332.

Deshmukh S S 1980 Geology, petrology and petrochemistry of the Deccan basalts in parts of Maharashtra state; Geological Survey of India, Unpublished report.

Deshmukh S S 1984 Petrography and petrochemistry of the Deccan basalts in Maharashtra; Geol. Surv. India Spec. Publ. 12 56-76.

Devaraju T C and Khanadali S D 1993 Lateritic and Bauxitic profiles of southwestern India. Characteristics and tectonic significance; Curr. Sci. 64 919-921.

Dogra N N, Singh Y R and Singh R Y 2004 Palynological assemblage from the Anjar intertrappean beds, Kutch, District Gujarat; Curr. Sci. 86(12) 1596-1597.

Fedden F 1884 The Geology of the Kathiawar Peninsula in Guzerat; Geol. Surv. India Memoir 21(2) 73135.

Frederiksen N O 1994 Middle and Late Paleocene angiosperm pollen from Pakistan; Palynology 18 91-137.

Gertsch B, Keller G, Adatte T, Garg R, Prasad V, Berner Z and Fleitmann D 2011 Environmental effects of Deccan volcanism across the Cretaceous-Tertiary transition in Meghalaya, India; Earth Planet. Sci. Lett. 310 $272-285$.

Gjems O 1967 Studies on clay minerals and clay mineral formation in soil profiles in Scandinevia; Meddelelser fra det Norske Skogsforsksvesen 21 303-415.

Hansen H J, Mohabey D M and Toft P 2001 No K/T boundary at Anjar, Gujarat, India: Evidence from magnetic susceptibility and Carbon isotope; Earth Planet. Sci. Lett. 110(2) 133-142.

Hansen H J, Mohabey D M, Lojen S, Toft P and Sarkar A 2005 Orbital cycles and stable carbon isotopes of sediments associated with Deccan volcanic suite, India: Implications for the stratigraphic correlation and Cretaceous/Tertiary boundary; Gondwana Geol. Mag. 8 5-28. 
Harward M E, Carstea D D and Sayegh A N 1969 Properties of vermiculites and smectites: Expansion and collapse; Clays Clay Minerals 16 437-447.

Hofmann C and Zetter R 2007 Upper Cretaceous pollen flora from the Vilui Basin, Siberia: Circumpolar and endemic Aquilapollenites, Manicorpus, and Azonia species; Grana 46 227-249.

Hopper P 1999 Winds of change, The Deccan Traps: A personal perspective; In: Deccan Volcanic Province (ed.) Subbarao K V, Geol. Soc. India Memoir 43 153-165.

Jackson M L 1979 Soil chemical analysis - advanced course, 2nd edn, published by W I Madison.

Jay A E and Widdowson M 2008 Stratigraphy, structure and volcanology of the SE Deccan Continental Flood Basalt province: Implications for eruptive extent and volumes; J. Geol. Soc. London 165 177-188.

Jay A E, Nicall C A, Widdowson M, Self S and Turner W 2009 New palaeomagnetic data from the Mahabaleshwar Plateau, Deccan Flood Basalt Province, India: Implications for the volcanostratigraphic architecture of Continental Flood Basalt province; J. Geol. Soc. London 166 13-24.

Kapoor B S 1972 Weathering of micaeous clays in some Norwegian podzols; Clay Min. 9 383-394.

Kar R K 1985 The fossil floras of Kachchh-IV. Tertiary palynostratigraphy; Palaeobotanist 34 1-280.

Kar R K and Kumar M 1987 Palaeocene palynostratigraphy of Meghalaya; Pollen et Spores 28 177-217.

Keller G, Adatte T, Gardin S, Bartolini A and Bajpai S 2008 Main Deccan volcanism phase ends near the $\mathrm{K}-\mathrm{T}$ boundary: Evidence from the Krishna-Godavari Basin, SE India; Earth Planet. Sci. Lett. 268 293-311.

Keller G, Adatte T, Bajpai S, Mohabey D M, Widdowson M, Khosla A, Sharma R, Khosla S C, Gertsch B, Fleitmann D and Sahni A $2009 \mathrm{~K} \backslash \mathrm{T}$ transition in Deccan Traps of central India marks major marine seaway across India; Earth Planet. Sci. Lett. 282(1-4) 10-23.

Keller G, Bhowmick P K, Upadhyay H, Dave A, Reddy A N, Jaiprakash B C and Adatte T 2011 Deccan volcanism linked to the Cretaceous-Tertiary boundary mass extinction: New evidence from ONGC wells in the KrishnaGodavari basin; J. Geol. Soc. India 78 399-428.

Khadkikar A S, Sant D A, Gogte V and Karanth R V 1999 The influence of Deccan volcanism on climates: Insights from lavcustrine Intertrappean deposits, Anjar, western India; Palaeogeogr. Palaeoclimatol. Palaeoecol. 147 141149.

Khosla A and Sahni A 2003 Biodiversity during the Deccan volcanic eruptive episode; J. Asian Earth Sci. 21(8) 895-908.

Krishnamurthy P, Pande K, Gopalan K and Macdougall J D 1999 Mineralogical and chemical studies on alkaline basaltic rocks of Kutch, Gujarat; Geol. Soc. India Memoir 43 757-783.

Leidelmayer P 1966 The Paleocene and Lower Eocene pollen flora of Guyana; Leidse. Geol. Meded. 36 49-70.

Li L and Keller G 1998 Maastrichtian climate, productivity and faunal turnovers in planktic foraminifera in south Atlantic DSDP sites 525DA and 21; Marine Micropaleotology 33 55-86.

Mathur Y K and Chopra A S 1987 Palynofossils from the Cenozoic subsurface sediments of the Bengal Basin, India; Geosci. J. 18 109-152.

Mishra K S 1999 Deccan volcanism in Saurashtra and Kutch, Gujarat; Geol. Soc. India Memoir 43 325-334.

Nair K K K, Chatterjee A K and Sano T 1996 Stratigraphy and geochemistry of the Deccan basalt along Toranmal section, western Satpura region; Gondwana Geol. Mag. 2 $23-48$.
Nair K K K and Bhusari B 2001 Stratigraphy of Deccan Traps: A review; Geol. Surv. India Spec. Publ. 64 477491.

Pal D K, Deshpande S B, Venugopal K R and Kalbande A R 1989 Formation of di- and trioctahedral smectite as evidence for paleoclimatic changes in southern and central peninsular India; Geoderma 45 175-184.

Pal D K, Bhattacharyya T, Sinha R, Srivastava P, Dasgupta A S, Chandran P, Ray S K and Nimje A 2012 Clay mineral record from Late Quaternary drill cores of the Ganga Plains and their implications for provenance and climate change in the Himalayan Foreland; Palaeogeogr. Palaeoclimatol. Palaeoecol. 356-357 27-37, doi: 10.1016/j.palaeo.2011.05.009.

Prasad B and Pundeer B S 2002 Palynological events and zones in Cretaceous-Tertiary boundary sediments of Krishna-Godavari and Cauvery basin, India; Palaeontographica Abt. B. 262 39-70.

Rao K P and Ramanujam C G K 1982 Palynology of Quilon beds of Kerala state in south Indian - II. Pollen of dicotyledons and discussion; Palaeobotanist 30(1) 68-100.

Retallack G J, Leahy G D and Spoon M D 1987 Evidence from paleosols for ecosystem changes across the Cretaceous/Tertiary boundary in eastern Montana; Geology 15 1090-1093.

Retallack G J 2010 Lataritization and Bauxitization events; Eco. Geol. 103(3) 655-667.

Salard Cheboldaeff 1978 Paleopalynologie du basin sedimentaire littoral du cameroun dans ses rapports avec la stratigraphie et la paleoecologie; Ph.D thesis, Univ. P. M. Curie, Paris, France.

Sah S C D and Kar R K 1970 Palynology of the Laki sediments in Kutch-3. Pollen from the bore-holes around Jhulrai, Baranda and Panandhro; Palaeobotanist 18 $127-142$.

Samant B and Phadtare N R 1997 Stratigraphic palynofloral of the Early Eocene Rajpardi lignite, Gujarat and the lower age limit of the Tarkeswar Formation of South Cambay Basin, India; Palaeontographica B245 $1-108$.

Samant B and Bajpai S 2005 Palynoflora from Lakshmipur intertrappean deposits of Kutch, Gujarat: Age implications; J. Palaeontol. Soc. India 50(2) 177-182.

Samant B and Mohabey D M 2005 Response of flora to Deccan volcanism: A case study from Nand-Dongargaon basin of Maharashtra: Implications to environment and climate; Gondwana Geol. Mag. Spec. Publ. 8 151-164.

Samant B and Mohabey D M 2009 Palynoflora from Deccan volcano-sedimentary sequence (Cretaceous-Paleogene transition) of central India: Implications for spatiotemporal correlation; J. Biosci. 34(5) 811-823.

Sarkar S and Singh H P 1988 Palynological investigations of the Subathu Formation (Eocene) in the Banethi-Bagthi area of Himachal Pradesh; Palaeontographica 209B 29-109.

Saxena R K 1990 A catalogue of fossil plants from India. Part 5A Cenozoic (Tertiary) A. Spores and Pollen; Birbal Sahni Institute of Paleaobotany, Lucknow, pp. 1-147.

Schultz L G, Shepard A O, Blackmon P D and Starkey H C 1971 Mixed-layer kaolinite montmorillonite from Yucatan Peninsula, Mexico; Clays Clay Minerals 19 $137-150$.

Shekhavat L S and Sharma V P 1996 Deccan Basalts of Wakaner-Rajkot area, Gujarat; Gondwana Geol. Mag. 2 89-100.

Sheth H C, Pande K and Bhutani R 2001a ${ }^{40} \mathrm{Ar} /{ }^{39} \mathrm{Ar}$ ages of Bombay trachytes: Evidence for a Paleocene 
phase of Deccan volcanism; Geophys. Res. Lett. 28(18) 3513-3516.

Sheth H C, Pande K and Bhutani R 2001b ${ }^{40} \mathrm{Ar} /{ }^{39}$ Ar age of a national geological monument: The Gilbert Hill basalt, Deccan traps, Bombay; Curr. Sci. 80 1437-1440.

Singh R S and Kar R 2003 Palynological assemblage from Deccan intertrappean Bed, Lalitpur, Uttar Pradesh, India; Gondwana Geol. Mag. 6 217-223.

Spicer R A 1989 Plants at the Cretaceous-Tertiary boundary; Phil. Trans. Roy. Soc. London B 325 291-305.

Srivastava P, Parkash B and Pal D K 1998 Clay minerals in soils as evidence of Holocene climatic change, Central Indo-Gangetic Plains, north-central India; Quat. Res. 50 230-239.

Srivastava S K 1968 Reticulate species of Aquilapollenites and emendation of the genus Mancicorpus Mtchedlishvilli; Pollen et Spores 18 665-699.

Subbarao K V, Chandrashekhar D, Navaneethakrishnan P and Hooper P R 1994 Stratigraphy and structure of parts of the Central Deccan Basalt Province: Eruption model; In: Volcanism: The Radhakrishnan volume (eds) Subbarao K V and Radhakrishna B, Wiley Eastern, New Delhi, pp. 321-332.
Venkatesan T R, Pande K and Gopalan K 1993 Did volcanism pre-year Cretaceous/Tertiary transition?; Earth Planet. Sci. 119 181-189.

Venkatesan T R, Pande and Ghevariya Z G $1996{ }^{40} \mathrm{Ar}-{ }^{39} \mathrm{Ar}$ ages of Anjar traps, western Deccan province (India) and its relation to the Cretaceous-Tertiary boundary event; Curr. Sci. 70 990-996.

West W D 1999 The petrography and petrogenesis of forty eight flows of Deccan Traps penetrated by borings in western India (reprinted from Trans. Nat. Sci. India, 1950, IV(1), pp. 1-56); Geol. Soc. India Memoir 43 641-704.

Whatley R and Bajpai S 2000 A new fauna of Late Cretaceous nonmarine Ostracoda from the Deccan Intertrappean beds of Lakshmipur, Kuchchh (Kutch) District, Gujarat, Western India; Rvi. Esp. Micropaleontol. 32(3) 385-409.

Widdowson M, Pringle M S and Fernandez O A 2000 A post K-T boundary (Early Eocene) age from Deccan-type feeder dykes, Goa, India; J. Petrol. 41 1177-1194.

Zachos J, Pagani M, Sloan L, Thomas E and Billups K 2001 Trends, rhythms, and aberrations in global climate $65 \mathrm{Ma}$ to present; Science 292 686-693. 